\title{
ENGLISH REASERCH
}

\section{Uses and Gratifications of Selfie photos and its Relationship with Self-Objectification, Self- Esteem and Personality Traits among Adolescents}

\author{
Dr. Sonia M. El-Sayad \\ A lecturer of psychiatric nursing and \\ mental health, Faculty of Nursing, \\ Port-Said University
}

\author{
Dr. Hany I. El-Batal \\ Assistant professor of educational media, \\ Faculty of Specific Education, \\ Port-Said University
}

\begin{abstract}
Background: selfie capture phenomenon is one of recently discussed issues, which attract much of different categories of persons especially adolescents. Previous researches correlated it with narcissistic behaviors and feeling of inadequacy.
\end{abstract}

Aim: to explore the relationship between adolescents' uses of selfie photos and their self objectification and self esteem levels as well as their personality traits. Methods: A total number of 1432 adolescent students from preparatory $(\mathrm{N}=$ $274)$, secondary $(\mathrm{N}=193)$ and university schools $(\mathrm{N}=965)$ were included in the study, they were recruited from five preparatory schools, seven secondary schools and six faculties from Port-Said city, Egypt. Six previously published questionnaires and scales with approved psychometric properties were used to collect the data of the present study, namely, attitudes towards selfie, self objectification questionnaire, objectified body consciousness scale, body esteem scale, self esteem, and personality traits questionnaire. As well as data related to selfie uses.

Results: Uses of selfie was correlated significantly with self objectification, body esteem and different traits of personality. Statistical significant differences were found between male and female students in relation to self objectification, objectified body consciousness, uses and attitudes towards selfie. Statistical significant differences were also observed between preparatory, secondary and university students concerning negative attitudes towards selfie, self objectification and body esteem. 
Conclusion: selfie could contribute to high self objectification and low body esteem. Moreover, it has been found that girls have higher levels of self objectification and objectified body consciousness. While, concerning boys, they assumed to have more negative attitudes towards selfie with more frequency of posting selfie photos on different social media.

What is already known about this topic?

- Selfie is worldwide phenomenon that increasingly affect person's life in many aspects

- Researchers were interested in studying selfie and link it with social and psychological variables

- Narcissism was the most common personality trait associated with selfie posting behaviors

\section{What this paper adds}

- Studying a non- wide spread phenomenon in Arabic community by assessing self objectification among adolescents

- Correlate selfie with variables such as body image and self esteem in order to explore its underling gratifications and uses.

\section{Background}

With the expand usage of social media and with the growing use of mobile devices among the different groups, especially teens, here came the development of technology for these devices in order to increase its uses and functions. One developing technology for these devices is the quality of the camera, which facilitates taking photos for others and self, while documenting valuable momentary of person's life (Wickel, 2015). That is why self portrait capture become tangible issues nowadays, persons tend to take selfies in more easier form; and with the concomitant expansion in the use of social networking sites and SNS platforms such as Facebook and Instagram, posting selfie they become able to share it with others in more interesting and enjoyable styles. Researchers and scientists were interested in studying this issue "selfie", due to its skyrocketing incidence and impressing novelty. Thus, further researches linked selfie with personality trait, specifically narcissism type (McCain, Borg, Rothenberg, Churillo, Wieler, Campbell, 2015; Paris, Pietschnig, 2015; Reed, 2015; Sorokowski, Sorokowski, Oleszkiewicz, Frackowiak, Huk, Pisanski , 2015; Kapidzic, 2013); personality related cues (e.g; Qiu, Lu, Yang, Qu, Zhu, 2015); self presentation and self expression in online sites (e.g; Poe, 2015) and identity development (Allen, 2015). Even researches who looked more 
deeper into selfie, studied emotional cues associated with selfies such as feeling of guilt, embarrassment, joy and frustration (McCain et al, 2015); expressions such as, duck face and other issues concerning sites, context, frequency and motivations (McCain et al, 2015; Weiser, 2015). On the same line Sarabia, Estevez, 2015 analyze the content of 100 profiles of teenagers and adolescents in Spain over 12 months and reported that sexualized behaviors are high among teenagers. On the other hand, a Norwegian study on 3763 users of social media was surveyed online in order to test the influence of age and gender on selfie behaviors. As assumed by the authors, females and adolescents tend to post personal photos and use photographic filters before posting selfies more than men and adult individuals (Dhir, Pallesen, Torsheim, Andreassen, 2015).

Looking at the previous studies, few studies concerning selfie were done. Investigating and looking into selfie with more deep vision and studying its related factors are recommended in order to develop a holistic identification of this phenomenon, variables concerning self such as; body image, self objectification and self esteem need to be carried out. Thus this research hopes to correlate selfie with new variables and study self objectification, body image, self esteem and personality traits and reveals its relationship with selfie among adolescents.

Self objectification is not a new phenomenon; it has been studied and postulated in 1997 by Fredrickson and Roberts. Their theory of self objectification posited that woman tend to view and value herself in terms of appearance rather than performance , and consequently it affect psychological health and wellbeing of woman resulting in many psychiatric disorders as eating disorders and depression. Unfortunately, this theory implies in its roots on only female persons and neglected men, thus few studies considered self objectification among men but relate it with issues such as body image. (McKay, 2013; Szymanski, Moffitt, Carr, 2011; Berberick, 2010; Aubrey, 2006a). Considering the person as an object, is a status which lowering humanity to inhumanity. Studies mentioned that objectification can be associated with gender roles, which build by societal beliefs and conceptions. Thus, society objectify persons and limit their roles according to cognitive and learning approaches, consequently and with reinforcement, persons begin to objectify self and see themselves through the perspective of body parts ( Quinn, Kallen, Twenge, Fredrickson, 2005). Objectifying self - especially among 
females- was also reinforced by media, relationships and cultures. In which societies view females as a sex object or representing them as regard to sexual body parts, thus self objectification is much referred to as sexual objectification (Aubrey, 2006b).

Regrettably, most of researches linked objectification to the ambiguously image of femininity and masculinity portrayed in media, which bind attractiveness with precise standards and perfection of body parts. Media played crucial role in shaping thoughts, reactions, life styles, beliefs, behaviors and images, previously, features of media were restricted to Television, Newspapers and Magazines, but currently social media has been expanded to various social networks, which contributes to sharing information speedily. Although social media has its benefits as; enhancing communication especially non verbal (Keller, 2013; Lenhart, Purcell, Smith, Zickur, 2010); increasing social interactivity ( Boyd, 2010), collaborating in group activities and assignments ( Borja, 2005) and fostering person's identity and social skills (Giedd, 2012; O〉Keeffe, ClarkePearson, 2011). On the other hand, further researches shown that social media usage has its negative consequences on individuals especially, teenagers. Shields and Kane, 2011, studied 450 college students from Public Commuter University in the Midwest, to investigate the relationship between internet usage and several social and psychological correlates, the study revealed that increased symptoms of depression, increased use of drugs and alcohol and various interpersonal problems were among the highly correlated problems with excess use of internet and social media. Other studies linked usage of social media and internet with loneliness (Kim, LaRose, Peng, 2009); stress (Dadoul, Jabareen, Sulieman, 2015), low self esteem and dependence (Mostafaei, Khalili, 2012).

Little attention and studies concerned the effect of media on psychological wellbeing, thus few researches had been done in relation to investigate the relationship between exposure to media objectifying personnel and psychological problems such as body dissatisfaction, low self esteem. On this context, Harrison and Fredrickson in 2008 studied 426 adolescent girls in order to test whether exposure to sports media lead them to objectify themselves, and mentioned that self objectification was high in the subjects and highly correlated with mental health risks such as body shame, eating disorders and depression. On the other hand, the study of Saguy, Quinn , Dovidio, Pratto, 2010 studied the effect of 
sexual objectification among women and found that women when objectified, they tend to narrow their social interactions especially in the presence of men.

In total, 226 undergraduate participants from a large, Midwestern U.S. University divided into 149 women and 77 men, Aubrey, 2006b study, concluded that exposure to objectifying media increase the trait of self objectification among the subjects, as they view themselves in terms of external traits rather than internal ones. He explained that by "exposure to televised objectification cultivates a particular view of the self, a view that emphasizes the importance of physical appearance". Giving attention to the outward appearance may lead to increase in self surveillance; which referred to the time spent by the persons closely observing on their bodies (John, Ebbeck, 2008). Therefore, persons who internalize objectification and value themselves in relation to their body parts may confront multiple challenges and issues in order to seek perfection. Thus they are vulnerable to various psychological problems as a consequence of objectification, such as body dissatisfaction, eating disorders (Bailey, Lamarch, Gammage , Sullivan, 2016; Jongenelis, Byme, Pettigrew, 2014; Kessler, 2010 ; Prichard \& Tiggemann, 2005), body shame, appearance anxiety, depression (Calogero, Tantleff-
Dunn,Thompson, 2011; Muehlenkamp, Swanson, Braush, 2005) and sexual functioning disturbance (Tiggemann, Williams, 2012). This extra concern with body may affect the persons' development of self concept and view of body image; in this context, further studies investigated the association between self objectification and body image and revealed that individuals who objectify their bodies are more susceptible to have negative body image and low self esteem regarding their bodies (Johnson, 2016; Liss, Erchull, 2015; Calogero, 2012; Calogero, Tantleff-Dunn,Thompson, 2011; Kessler, 2010; Downs, James, Cowan, 2008; Ilaria, 2006).

Body image is a crucial connotation for adolescence; it does contribute substantially with the development of self concept; which affects persons' evaluation of self and others. Further studies revealed that dissatisfaction concerning body image may strongly correlated with depression, eating disorders and low self esteem (Goldenberg, Cooper , Heflick , Routledge , Arndt. 2011; Gupta, 2011; Berg, Mond, Eisenberg, Ackard, Neumark-Sztainer, 2010; Hamilton 2008; Holsen , Kraft , Røysamb. 2001).

Adolescence considered a transitional stage of age, from childhood to adulthood. This period of transition is full of physical, mental, behavioral and 
psychological changes that require proper response, acceptance and adaptation (Meeus, Van de Schoot, Klimstra, ,Branje, 2011). Because adolescence is a pivotal stage, many theorists started to study this period, in relation to Freud theory, personality development ends with adolescence (McLeod, 2013a). On the other hand, Erikson's theory of personality development argued Freud theory and assumed that personality developed along eight stages of development, focusing on tasks that should be attained by the person. In his theory Erikson viewed adolescence as a critical period, in which person develops his identity and answer the question of "who I am?" (McLeod, 2013b). Literatures of review revealed various models explaining types of personality, among these models the Big five model of personality traits, which concluded that personalities are usually evolve around five types namely; Openness to experience, Conscientiousness, Extraversion, Agreeableness and Neuroticism. Persons with high openness to experience tend to enjoy life, make adventures while persons with low high openness to experience tend to limit their experiences especially the new ones. Conscientiousness refers to the trait of the person which makes him independent, responsible and disciplined. The trait
Extraversion is high among sociable, assertive and cheerful personnel, while agreeable is high among compassionate, helpful and trusting individuals. Finally persons with low scores on Neuroticism trait tend to be more mentally and emotionally stable (Pappas, 2013; Judge, Bono, 2000).

\section{Theoretical Framework}

This study depended on the theory of uses and gratifications as a theoretical inference. As this theory can be used in identifying the actual reasons and needs behind the widely spread use of selfportrait photos among adolescents.

\subsection{Uses and Gratifications Theory.}

This theory of the important theories in the world of modern media studies that are trying to understand the media process, as well as trying to explore how and why people use media and what motivated their exposure to its different means. This theoretical content is trying to answer a question: why people need media? What are the needs and motives behind media usage?, in other words: what is the effect of media on people?

The exposure to media, is one of the interesting issues that preoccupied professionals and workers in the media field for a long time. Therefore, researcher were interested in assessing needs and 
benefits from exposure to media. Some might think that the easy-to-answer question based on the theory that people use communication media in order to know the news and interpret events, leisure and entertainment, learning, education, dating, social interaction and other customary functions (Werner and James, 2000).

The theory of uses and gratifications came through the industrious activity of katz, Plummer and Gurevitch and their theoretical ideas through their book «uses of mass communication, the theory based on that individuals are motivated by psychological influences, social and cultural make them in need of Media and Communication. According to the theory, uses and gratifications approach are based on five components, listed as follows (Katz, Blumler, and Gurevitch).

\section{First: the motivations and needs:}

Need is refer to «a certain lack of human feeling psychologically and socially in which its gratification lead to a state of satisfaction and happiness.

On the other hand, motive means internal, physiological or psychological stimulants enforce individual to perform a particular behavior strengthens its response.

Usually the degree of motivation could be measured by in several recipes, as the energy expended and continuing diversity.

According to the theory, satisfying needs, desires and motivations is psychological and social necessity for individuals, it can contribute to their psychological equilibrium and social adjustment with the environment.

In this area there are numerous human needs are in the context of «happiness, intimacy, knowledge, beauty, family , friends, security ,understanding, respect, law, freedom, personal and social identity «(Denis,2010)

Second: the motives of exposure to the media:

According to media studies, the motives of media determined by some variables; individuals, means, content, exposure and conditions.

thus it can be summed up that motives of human exposure to the media could be explained as follows:

1. Get knowledge, news and communicate with the local and international community.

2. Escape from the problems and differences and disturbances and search for a world of pleasure, comfort and imagination.

3. Coexist and communicate with others and find a base of friction and social affiliation.

4. Get a dimension for solitude and 
escape from the daily routine and life pressure.

5. Find support for individual values and traditions.

\section{Scientists divided motives into two}

\section{parts:}

a. designed and structured motives;

It is the type of motives fulfilling the personal benefits, such as gaining knowledge, and information from the world, which may appear to be more pronounced in the programs and interpreting news (Stanley and Dennis, 2009).

b. ritual and recreational motives.

it is aiming at fulfilling needs for satisfaction, happiness, relax , escape from the mental and emotional problems. This type could be gained from media appear in the films, entertainment programs and recreational media).

Third, needs fulfilled by exposure to the media:

Those needs can be summarized in the following items:

1. Recreation: Through having fun and this leads to escape from the routine and emotional pressures.

2. Perception: gaining knowledge from news and information, which can contribute to perceive self, others and events in more precise way.
3. Withdrawal: individuals need to escape from difficulties and the pressures of life through using different methods, and one of them is the media .

4. Group use: programs, articles, meetings and reports, which lead to the strengthening of integration within families, communities and friends(Katz, Blumler, and Gurevitch). .

\section{Fourth: expectation and gratification} from media:

Gratifications might vary according to the public exposure to the media, so it can be linked to expectations of the public from these means. Expectation is a specific property penalty and the possibility expected by the public from the means, and here says Mendelsohn and Katz, that are the demands of the public media exposure.

So we find that the gratification can be associated with positive expectation from the media (Katz, Blumler, and Gurevitch).

For example, when an individual is expected that using self- portrait is interesting and fun ,the degree of gratification will be increasing and mostly fulfilled.

The most important gratifications could be summed up as follows:

1. Immediate gratifications; derived 
from immediate exposure to media

2 . Slow gratifications; belatedly occur on long-range trends, such as the formation of opinions and attitudes.

3. Releasing gratifications; aiming at helping individuals to get rest and get rid of anxiety and turmoil.

4.Environmental gratifications, monitoring, help individuals to access information, knowledge and interpretation.

5. Content gratifications: is caused by exposure to the contents of types of media as; Movies, News, drama and Photos " e.g. self-portrait photos"

6. Processing gratifications: occur as a result of the link between exposure and the manner (e.g, peopless habits in dealing with different medias, for example, sitting watching TV directly when you return to home, or exposure to social networks during the day, reading a newspaper at work and finally as taking selfie photos in special occasions).

7. Achieved gratifications: that occur due to the continuous exposure to media in general.

8. Needed gratifications: which individuals are trying to fulfill (e.g. internet use and capturing self- portrait photos)

9. Personal /self-gratifications: they earn individual with some developmental skills (arts, expertise, knowledge, developed behaviors and habits)

10. Social gratifications: they helped the individual to deal and integrate with the network of social relations within the community(Denis, 2010; Katz, Blumler, and Gurevitch).

\section{Fifth, the audience are active and reactive.}

The theory of uses and gratifications did not ignore public nature and their choices. Thus the theory proposed that:

- Public is active, means that individuals can choose to select different means of media according to their interests and their own temperaments, for example, various studies stated that adolescents may prefer to use selfie more than use of other types of photos.

- Public is not negative receivers, they not only receive information but instead and has the ability to act as well as interact, and sometimes may has the (immunity) against the influence of the media.

Thus it can be assumed that the audience has the ability to choose and take decisions in regard to his exposure process and understanding in three levels; namely

1. Selectivity, which means that the public choices is not random instead they choose the means, content, and means of medias.

2. Benefit, which means that audiences 
are motivated to usage of medias according to the benefits they gain from it.

3. Preoccupying, which refers to the active role of the audience in receiving different contents of media ( Mark, Windahl, 1985).

\subsection{Selfie Photo and Media}

The word selfie refers to a self-portrait picture taking by oneself using a digital camera or a smartphone, it became a new medium for self-expression and self-representation (Unmertic, 2014). The selfie has a long history, but in the past couple years the phenomenon has become more prominent due to the confluence of front-facing cameras on smartphones and tablets, faster and wider distributions of wireless network and a cultural proclivity of online selfpresentation and representation assisted by the popularity of social networking sites like facebook and twitter. Selfies may also be a modern tool for self-exploration and self-expression. According to Dr. Jana Mohr-Lone, the Head of University of Washington's Philosophy for Children Department, taking selfies and getting comments or likes had helped the young people to connect with their own world (Johnson, 2013).

Truly, social media has allowed us to have more personal control over how we present ourselves to others. we show our public self or what we think is pleasing for everybody. Selfies can increase the self-esteem and self-efficacy as it highlights what youngsters are going through. Selfies can also enhance the self-presentation by posting what is socially desirable (Abidin \& Thompson, 2012).

In social media nearly $30 \%$ photos are selfies taken by adolescents and more than 1 million selfies are taken every day. In a survey conducted by the Pew Research Center, teens expressed that facebook is an extension of their social communication and an essential component to their social life. specifically, teens measure their status through the number of "likes" a photo shared or a status updated. As a way to acquire the maximum number of likes (Aboujaoude, 2011) Facebook users will manipulate and change their profile content. Managing and revising one's profile content is a vital aspect of an adolescent's online identity. Nearly $52 \%$ of adolescents online express they have had an experience through a social networking site that boosted their confidence (Duggan and smith, 2013).

Selfie reflect the four most themes: duality, insecurity, freedom of expression and the communication gap between adolescents and adults. For today's teens, social media profiles turn into a visual 
diary of development, through which young people may scroll, looking for something that they have yet to learn about themselves. They may judge themselves harshly compared to their peer, or alter their behavior so that their digital image will be more acceptable to others (Nunez, 2013).

Another study assessed motives for social network site (SNS) use, group belonging, collective self-esteem, and gender effects among older adolescents. Participants high in positive collective self-esteem were strongly motivated to communicate with peer group via SNS (Barker, 2009).

Social network sites, such as Facebook, have acquired an unprecedented following, shows that Facebook profiles are self-affirming in the sense of satisfying users $>$ need for self-worth and self-integrity. Facebook users gravitate toward their online profiles after receiving a blow to the ego, in an unconscious effort to repair their perceptions of selfworth (Toma and Hancock, 2013) . A study aimed to prospectively examine the role of peer and media influences in the development of body satisfaction girls $>$ desire for thinness and it was found to temporally precede low self-esteem. negatively influences the development of body image and self-esteem (Dohnt and Tiggemann, 2006). Results showed that girls who regularly shared self-images on social media, relative to those who did not, reported significantly higher overvaluation of shape and weight, body dissatisfaction, dietary restraint, and internalization of the thin ideal. In addition, among girls who shared photos of themselves on social media, higher engagement in manipulation of and investment in these photos, but not higher media exposure, were associated with greater body-related and eating concerns, including after accounting for media use and internalization of the thin ideal ( McLean, Paxton, Wertheim and Masters , 2015).

Theory on Self-Presentation described how individuals perform roles to project a desired impression to others. Currently, social media platforms allow persons to share their lives and interests with a wide-reaching audience. Instagram was used to provide motivation, knowledge, and feedback to women in relation to their fitness journeys. (Lupinetti, 2015).

\section{Objectives of the study}

The study aims to explore the relationship between adolescents' uses of selfie photos and their self objectification and self esteem levels as well as their personality traits. It is hypothesized that selfie capturing and sharing on social media will be differed significantly in 
its scores among the studied subjects (Hypothesis 1). Furthermore, male and female students will differ in their mean scores of self objectification, body esteem, self esteem and uses of selfie (Hypothesis 2). Based on previous researches results, it is proposed that female students will have positive attitudes towards selfie (Hypothesis 3).

Moreover, the previously mentioned literature referred to body image as a significant indicator in relation to selfie capturing and posting on social media. Thus, it is assumed in this study that self objectification, objectified body consciousness and body esteem will be correlated significantly with adolescents' selfie attitudes (Hypothesis 4).Finally, Based on previous researches which linked selfie with narcissistic personality, it is assumed that selfie capturing and posting will be correlated significantly with other traits of the personality (Hypothesis 5).

\section{Methods}

\subsection{Participants and Procedure}

A total number of 1432 adolescent students from preparatory $(\mathrm{N}=274)$, secondary $(\mathrm{N}=193)$ and university schools $(\mathrm{N}=965)$ were included in the study, they were recruited from five preparatory schools, seven secondary schools and six faculties from Port-Said city, Egypt. The total number of selected schools and students were determined under the consideration of randomization and to give best representation of the study population. Tools were distributed on students in each setting of the study after explaining the aim of the research and take students' consent to participate in the study. Researcher was available for any explanations and collected the tools after completion. Data were collected three times per week from 13 October 2015 to 7 June 2016.

\subsection{Measures}

Six previously published questionnaires and scales with approved psychometric properties were used to collect the data of the present study. A questionnaire assessing socio-demographic characteristics of the adolescents such as gender, age and residence, in addition to data concerning selfie posting behaviors such as frequency, type and the preferred look associated with selfie, was developed by the researcher in order to attain the objectives of the study.

Attitudes towards selfie. Students were assessed in regard to their attitudes towards taking selfie and sharing it on online different social media sites, using a developed scale by Paris and Pietschnig in 2015. The scale is consists of 54 items on 6 likert- type scale ranging from 
strongly disagree to strongly agree.

Self objectification. Was measured using two assessing tools, firstly, Self Objectification Questionnaire, which were developed by (Noll, Fredrickson, 1998) and translated to Arabic language by the researcher. The tool is consisted of ten items ranked from 1 ( least important) to 10 ( most important) measuring respondents' perception of their different body attributes. It includes five items related to competence and five items regarding appearance- based attributes. Total scores of the questionnaire ranged from -25 to 25, with high scores appeared in relation to high self objectification. As second tool was used in order to assess self objectification, namely Objectified Body Consciousness Scale; it was developed by (McKinley, Hyde, 1996), and translated to Arabic language by the researcher. It consists of three subscales ; Body Surveillance ( defining body as perceived by the respondents), Body Shame ( measuring respondents' view of their body in relation to social and cultural standards), and Appearance Control Beliefs ( measuring respondents believe that they could control their body with different ways). It includes 24 items on likert scale ranging from 1 (strongly disagree) to 7 (strongly agree). The total score ranged from 24 to168.

Body Esteem. Was assessed in order to measure the extent to which adolescents were satisfied about their body. The tool is 21 item- scale, developed by (Mendelson, Mendelson, White, 2001) and translated to Arabic language by the researcher. Answers were ranged from 1 (never) to 5 (always). After reversing scores of negative items, the total score calculated and respondents indicated high scores, proposed to have high body satisfaction.

Self Esteem. Using Rosenberg Self Esteem Scale (Rosenberg, 1965) as the most widely- used tool, adolescents' self esteem was assessed. The scale contains 10 items, supposing high scores to be related with high self esteem.

Personality. Big Five Personality Traits Questionnaire was used in order to assess the different traits of adolescents' personality. It consists of 44 items measures five dimensions namely, Extraversion vs. introversion (statements: 1, 6, 11, 16, 21, 26, 31, 36); Agreeableness vs. antagonism (statements: 2, 7, 12, 17, 22, 27, 32, 37, 42); Conscientiousness vs. lack of direction (statements: $3,8,13$, $18,23,28,33,38,43)$; Neuroticism vs. emotional stability(statements: 4, 9, 14, 19, 24, 29, 34, 39), and Openness vs. closedness to experience (statements: 5 , $10,15,20,25,30,35,40,41,44)$. Answers ranged from 1 (strongly disagree) to 5 (strongly agree) and then total scores 
of each dimension calculated to reveals facets and correlated trait adjectives of personality.

\section{Data Analysis}

Descriptive statistics of the present study was measured by means, minimum, maximum, skewness and kurtosis values. To test hypothesis1, (i.e. compare between the three groups in relation to self objectification scores), analysis of variance (ANOVA) was used in order to represent whether the studied adolescents differ in the mean scores of the studied variables. Independent sample t-test was used also in order to test hypothesis 2 and 3 (i.e. difference between males and females in regard to their selfie attitudes scores). Pearson's coefficient correlations were used to explore the association between the variables (Hypothesis 4, 5). A series of multiple regression analysis were used in order to predict the power effect of self objectification, body esteem, body consciousness and personality traits on the attitudes towards selfie capturing and posting on social media (Hypothesis 4, $5)$. The power of each predictive variable was determined by its standardized coefficient (Beta), which reflect the effect of the variable on the outcome. The unstandardized coefficient, standard error and standardized coefficient for each regression equation are presented, as well as P-value and 95\% confidence intervals. Statistical significance was set on .05 while highly statistical significance was set on .01. IBM SPSS Statistics version 20 was used for all analysis.

\section{Ethical Considerations}

An approval was obtained from the administrative authorities of the preparatory, secondary schools managers and Faculties deans of the studied settings via official letters directed to all of them from the Faculty of Nursing, Port Said University. Adolescent students were voluntarily recruited in the study. The aim of the study was explained to both of them and participation was entirely voluntary; they had the right to determine their willingness or refusal to participate in the study and to withdraw from the study at any time prior to submitting the completed questionnaire forms, which were anonymous to protect their identity.

\section{Results}

\subsection{Characteristics of the respondents}

Almost two thirds of the adolescents $(60.3 \%)$ were aged between 1820 - years old, with higher percentage referred to female subjects $(60.9 \%)$. Table 1 .

\subsection{Descriptive statistics}

The total mean scores of the studied variables were illustrated in table 2 . As 
revealed in the table, the highest mean value related to attitudes towards selfie showed in considering selfie as a pastime. On the other hand, the mean value of the objectified body consciousness dimensions was body shame, which is a considerable result. Regarding personality, the table presented that conscientiousness was the highest in mean values among the other traits of personality.

\subsection{Comparative results}

As presented in table 3. Almost half of the respondents (46.7\%) reported to take personal selfie photos, with high percentage showed in secondary school adolescents (52.3\%). Looking at frequency of selfie capturing, about half of the subjects stated to capture more than 8 photos per day $(51.7 \%)$, with highest percentage showed in university students $(52.6 \%)$. A statistical significant differences found between the three groups and frequency of selfie posting in social media, $\mathrm{F}=55.56$ (.000). About half of the three groups mentioned that they use selfie due to its easiness and uniqueness (47.4\%, 53.4\% and $47.6 \%$ respectively). Another statistical significant differences were presented between the three groups and the use of photo editing program before posting selfie photos on social media, $\mathrm{F}=8.20$ (.000). More than one quarter of the preparatory students $(29.9 \%)$ stated that they preferred to look sexy and attractive on selfie photos, as compared to $25.9 \%$ and $24.2 \%$ of the secondary and university students respectively (Hypothesis 1).

Table 4 revealed that there were statistical significant differences found at P-value $>0.01$ between the three groups (preparatory, secondary, university) in relation to negative opinions toward selfie, self objectification, objectified body consciousness, body esteem, self esteem and different traits of personality.

Statistical significant differences have been observed between male and female studentsatP-value $>0.01$ inrelationtomean scores of self objectification, objectified body consciousness, extraversion, agreeableness, conscientiousness and openness to experience, dimensions of attitudes toward selfie (Hypothesis 2 ). Results presented in table 5, also recorded that female students had a lower mean scores in regard to posting their selfie photos on different social media, but on the other hand, they attempt to use photo editing programs more than males. Concerning male adolescents, results revealed that they have more negative opinions regarding selfie than female ones (Hypothesis 3).

\subsection{Correlational analysis}


Self objectification as well as objectified body consciousness were correlated positively and significantly with dimensions of attitudes towards selfie (i.e. pastime, travel, status symbol), and correlated negatively and significantly with negative opinions towards selfie. The table also revealed that as the body esteem scores increased, the scores of self objectification decreased. Moreover, self esteem was correlated positively and significantly with objectified body consciousness and body esteem. Moreover, personality traits of the studied adolescents (i.e. extraversion, agreeableness) were correlated positively and significantly with objectified body consciousness, body esteem and self esteem. In the same times all personality traits were correlated negatively and significantly with negative opinions towards selfie. Results presented in table 6 (Hypothesis 4).

Table 7 shows data related to selfie taking and sharing in correlation to the studied variables. It is clear from the table that self objectification was correlated negatively with frequency of posting selfie on social media sites $(r=$ $-.127, \mathrm{p}<.01)$ and positively with times of capturing photos before posting it $(r=.369, p<.01)$. Persons with high levels of self objectification have increased times of capturing photos before posting and prefer to look attractive in their photos. On the other hand, body esteem seemed to be decreased in adolescents whom use programs to edit their photos before posting them $(\mathrm{r}=-.084, \mathrm{p}<.01)$. Moreover, self esteem levels seemed to be correlated positively with causes of selfie posting $(\mathrm{r}=.062, \mathrm{p}<.05)$.

Looking at personality traits, it has been explored that adolescents with extraversion personality tend to post more than 8 photos per day and preferred to look sexy in those photos $(r=.170, r=$ $.095, \mathrm{p}<.01$ respectively). While persons with agreeableness and conscientiousness traits found to post from 6 to 8 photos per day with four numbers of attempts to capture photos at first in neutral look (Hypothesis 5). Finally, adolescents with openness trait seemed to prefer the sexy look in their photos with tendency to decrease use of photos editing programs $(\mathrm{r}=.092, \mathrm{r}=-.103, \mathrm{p}<.01$ respectively $)$.

\subsection{Regression analysis}

After the results of hierarchical regression analysis using self objectification, extraversion, neuroticism and openness to experience traits of personality as predictors of positive attitudes towards selfie, it can be claimed that self objectification was a significant negative predictor of $8.7 \%$ for the variance in positive attitudes towards selfie. In 
the second step, self objectification was controlled and extraversion was entered, and it has been cleared that extraversion was also a significant predictor with a percent of 12.3 of variance in positive attitudes towards selfie.

As the tables (8 and 9) show, neuroticism trait personality was also a significant negative predictor and accounted for $13 \%$ of variance in positive attitudes towards selfie. Finally, openness to experience trait which was entered in step 4, explained an additional $13.6 \%$ of the variance in positive attitudes towards selfie (Hypothesis 4, 5). These presented results revealed that the regression equation aiming at predicting positive attitudes towards selfie taking and sharing can be calculated as follows: - -295 (self objectification $)+-.190$ (extraversion) + -.089 (neuroticism) +-.079 (openness to experience).

\section{Discussion}

Despite selfie is not a new phenomenon, academic researches concerning its relationship with different social and personal data still in need. In recent years, it has been noted that selfie was associated with recording all everyday living activities (e.g. intimate relationship' circumstances and private conditions), special spiritual activities (e.g. Al-Hag in Islamic religion), as well as some dramatic accidents worldwide. Thus, it was interesting for the researcher to study this ambiguous behavior and correlates it with personal variables; self objectification, body esteem, self esteem and personality traits in order to reveals some of its mysterious aspects.

\subsection{Comparison results}

Statistical significant differences found between preparatory, secondary and university students in relation to frequency of posting selfie photos on social media and use of photos editing program, with highest percentage showed in university students. Which might be explained by the enterprise personality of those students, who could be more dauntless and courageous than younger students, as well as they were noted to be more satisfied with their bodies' presentation (SeongPek, 2016; Qadir, 2016; Gallivan, 2014; Gattario, 2013). As regard use of photos editing programs, this result might be explained by the magnificent concern with the developed technology and varied programs, which increase the partiality of trial of new experiences during adolescence. This result is consistent with the results of Dutta et al, 2016, who conducted a study on adolescents and their attitudes towards selfie and reported that the studied adolescents stated that they use photo editing programs. 
In the same context, the present study revealed that there were statistical significant differences between the three studied groups in regard to negative opinions towards selfie (dimension 1 of attitude scale toward selfie); especially among preparatory students who reported that selfie could be considered as a waste of time and useless behavior. Allen, 2015 agreed with this result and elaborated in a study linking selfie with identity formation, that some of the participant view selfie as a time consuming. Moreover, some participants were unsatisfied with their selfie photos and saw themselves as uncomfortable and annoying. While Houghton, Joinson, Caldwell and Marder, 2013 in their discussion paper about effect of information sharing in Facebook on personal relationships, contradicted this result and stated that photo sharing was correlated positively with feelings of support and intimacy.

Moreover, students were differing in their scores of self objectification and objectified body consciousness especially among preparatory students. This might be due to that body image is so crucial to persons especially in younger adolescents; their view of self is more attributed with their satisfaction towards their bodies. They may be also evaluating their selves in relation to how the body looks more than how it feels, because of the great impact and emphasis of culture on the look of the body and the body related beauty standards. Thus they scored low in the objectified body conscious scale. In this context, Claudat, 2013 study results showed that self objectification was positively correlated with body shame and negatively with body satisfaction

Concerning personality traits, results illustrated that preparatory and secondary students have high means on conscientiousness, while university students scored high on openness to experience personality trait.

Finally completing the comparative results, it has been explored that female students have higher levels of self objectification and objectified body consciousness than male students. This is one of the expected results of this study, women are surrounded by many social norms and traditions link their selves and societal values with their body attributes. Especially our Arab community, which put a great emphasis and a heavy burden on females' beauty standards; and consequently make women internalize those standards and norms as well as influence their body perception and satisfaction. But studies of Vandenbosch and Eggemont, 2014 and particularly the study of Ilaria, 2006 who tested the full objectification model, as elaborated 
by Fredrickson \& Roberts, 1997, and its relationship with body image and depression, contradicted this result as it was found in her study that men were experiencing self objectification as well as female subjects, with no significant differences. Media and its innovative means was the most significant reported cause of high levels of self objectification among males and females (McKay, 2013; Dohnt \& Tiggemann, 2008). In consistence with this result, Grabe, Hyde and Lindberg, 2007 revealed in their study that women are objectifying their selves and feel ashamed with their bodies more than men.

Male students have been reported to have more negative opinions toward selfie and in the same time they have higher frequency of posting their selfie photos via social media. Those students may perceive selfie experience as pointless, embarrassing and not cool; moreover, they stated that it is attention seeking behavior (Marciniac \& Budnarowska, 2015). But men had been reported across different cultures and academic researches to be more intrepid and dare concerning their social presentation and expression, this might be the explanation behind their selfie photo posting. But this findings were inconsistent with (Sorokowski et al, 2015), as they studied selfie posting behaviors in comparison to gender and reported in their study that female subjects had higher mean scores of posting selfie photos. Furthermore, Selfiecity, which is a project supported by The Graduate Center, City University of New York, investigated the styles of selfie in different five cities across the world in 2014, and concluded from this study that women are more likely to post selfie photos than men.

\subsection{Correlational results}

The results of correlation between the studied variables and attitudes towards selfie reflected that negative attitudes towards selfie are increasing if scores of self objectification and body esteem is low and vice versa. This is reasonable result in which persons who objectify their bodies and feel ashamed; view selfie as a negative and unfavorable experience. Moreover, viewing selfie as a pastime was pointed out to be increased if students' levels of self objectification and objectified body consciousness increased too. This result could be linked also with the previously mentioned explanation, but this result did not support the existing researches of Fox \&Rooney, 2015 that referred in their study that self objectification was correlated positively with the self presentation on social network sites.

On the other hand, results revealed that 
highly self objectified adolescents tend to not post their selfie photos via social media sites, because they feel ashamed and worried about their appearance ( Calogero, 2012), as well as, they might fear of the evaluation and judgment of others regarding their look in the photos. Students also reported that they evaluate the photos in regard to the number of likes and comments of others. This lends credence to the previous results of (Wagner, 2016).

One of the striking results of the present study is that self esteem correlates only with objectified body consciousness and body esteem in positive way, which is a realistic result too. Theories explained self esteem linked it with self concept; in which one of its vital dimensions are self esteem and body image; which spot light on the interrelationship between mind and body. In the same context, use of photos editing programs decreased in students who scored high in body esteem, agreeableness, conscientiousness and openness to experience. Indeed, persons who are highly satisfied with their bodies and have a realistic view of self tend to not use those programs. This corroborates the earlier findings of Sorokowska et al, 2016 and Paris \& Pietschnig (2015) who conducted an exploratory study on university students' attitudes towards selfie and reported that self esteem did not correlates with students' attitudes. At the same context Ní Mháirtín, 2016 stated that self esteem fad no significant correlation with frequency of selfie taking.

Persons with extraversion personality in this study seemed to have high scores of body esteem, and increased number of capturing and posting selfie photos. Extraverted persons are assertive, positive in their emotions and they gain their social energy from participation with other, moreover, they assumed to be talkative and have noticeable attentionseeking behaviors, thus they are prone to expose their lives, activities and conditions to others via social media as well as they had high body esteem. On this context, Paris \& Pietschnig (2015) stated that extraversion was associated with higher scores with positive attitudes towards selfie photos. While Ní Mháirtín, 2016 found after studying the 'selfies', self-esteem and introversion in young persons live in Ireland and Hong Kong, that there was a weak correlation between frequency of selfie take and introversion / extraversion trait of personality.

\subsection{Regression results}

Of special interest in the present results is that extraversion, neuroticism and openness to experience are significant predictors of adolescents' 
positive attitudes towards selfie. Indeed, persons who characterized by sociability, assertiveness and energy as extraverted; persons who are imaginative, independent, curious and adventurer as persons with openness personality have a higher tendency to present and review their selves with no shy and fear from comments or others evaluation.

In the same context, it has been found that self objectification is the best predictor of positive attitudes towards selfie among the studied adolescents. A probable explanation of this result is that satisfaction with body and evaluating self in terms of functions and not appearance expected to be associated with positive and satisfactory attitudes towards self, and hence towards self presentation which may take many forms as capturing photos and sharing it. This result was in accordance with Fox \& Rooney, 2015 who reported that self objectification is a prevalent predictor of use of selfie. And a vice versa study stated in its results that internet exposure (e.g. selfie photos) is predict self objectification (Tiggemann and Slater, 2015 )

\section{Future researches, Implications and Conclusion}

Several findings of the present study suggest some recommendations, firstly, increase awareness of the adolescents regarding uses of selfie and its hazardous effects, through holding sessions and workshops to adolescents in their schools about selfie and its relationship with high self objectification and low body esteem. Second, self objectification recorded in this study to be high in female adolescents, thus it is recommended that those students have to stop internalize high cultural beauty standards and view their selves in relation to their body appearance, this could be attained through teaching the women to identify their strengths and specifications which may contribute to their self esteem and consequently their bodies image.

In the same context, media and its means (i.e. social media sites) was revealed as one of the most significant cause of high self objectification and low body esteem, thus further studies and researches between psychiatric nursing and new media specialty should be expanded in order to identify the different effects and impacts of media on mental and psychological wellbeing. Finally, through the results of the present study and other researches (i.e. Burriss, 2016; Sorokowska , 2016; Shah, 2015) the extra capture of selfie photos could contribute to addiction. Thus students and their parents should realize this issue and consequently, limit uses of selfie and posting. 
Through the results of this research, it can be concluded that selfie could contribute to high self objectification and low body esteem. Moreover, it has been found that girls have higher levels of self objectification and objectified body consciousness. While, concerning boys, they assumed to have more negative attitudes towards selfie with more frequency of posting selfie photos on different social media. Finally, frequency of posting selfie was correlated with extraversion, agreeableness, conscientiousness and openness to experience traits of personality, while, neuroticism was the most negatively correlated trait in relation to attitudes towards selfie.

\section{Conflict of Interest}

The author declare no conflict of interest

Funding

No funding

\section{References}

- Abidin C \& Thompson EC. (2012): „Cyber femininities and commercial intimacy in blogshops"e, Women "s Studies International Forum, 35, 467 -477.

- Aboujaoude E. (2011): Virtually you: The dangerous powers of the e-personality. New York: W.W. Norton.

- $\quad$ Allen S. (2015): «Adolescents, Social
Media, and the Use of Self-Portraiture in Identity Formation. Published Thesis. Faculty of the Department of Marital and Family Therapy. Loyola Marymount University. LoyolaMarymountUniversity, and LoyolaLaw School Theses and Dissertations. Paper 150. Available at: digitalcommons.lmu.edu/cgi/ viewcontent.cgi?article $=1159 \&$ context $=$ etd. Aubrey J. (2006a): Effects of sexually objectifying media on self-objectification and body surveillance in undergraduates: Results of a 2-year panel study. Journal of Communication, 56(2):366386-.

Aubrey J. (2006b): Exposure to Sexually Objectifying Media and Body Self-Perceptions among College Women: An Examination of the Selective Exposure Hypothesis and the Role of Moderating Variables. Sex Roles: A Journal of Research, 55(3): 159- 72.

- Bailey K, Lamarch L, Gammage K, Sullivan P.( 2016): Self-Objectification and the Use of Body Image Coping Strategies: The Role of Shame in Highly Physically Active Women. The American Journal of Psychology, 129(1): pp. 8190-.

- Barker V. (2009): Older adolescents> motivations for social network site use: the influence of gender, group identity, and collective self-esteem. Cyberpsychol Behav. 2009 Apr;12(2):20913-.

- BerberickS.(2010):TheObjectification of Women in Mass Media: Female SelfImage in Misogynist Culture. The New York Sociologist, Vol. 5: 116-.

Berg P, Mond J, Eisenberg M, Ackard D, Neumark-Sztainer D. (2010): The link between body dissatisfaction and selfesteem in adolescents: Similarities across 
gender, age, weight status, race/ethnicity, and socioeconomic status. Journal of Adolescence Health. 2010 Sep; 47(3): 290-296.

- Borja RR.(2005): "Blogs" catching on as tool for instruction: teachers use interactive Web pages to hone writing skills. Education Week.

- Boyd D. (2007): Why youth (heart) social network sites: the role of networked publics in teenage social life. In: Buckingham $D$ ed. MacArthur Foundation Series on Digital Learning: Youth, Identity, and Digital Media Volume. Cambridge, MA: MIT Press. Available at:www.danah.org/papers/ WhyYouthHeart.pdf.

Calogero R, Tantleff-Dunn S, Thompson JK. (2011): Self-Objectification in Women: Causes, Consequences, and Counteractions. American Psychological Association Books.

- Calogero RM. (2012): Objectification Theory, Self-Objectification, and Body Image. Encyclopedia of Body Image and Human Appearance, 2: 574-80.

- Claudat K. (2013): The Role of Body Surveillance, Body Shame, and Body SelfConsciousness during Sexual Activities in Women «s Sexual Experience. A published master thesis. Department of psychology. University of Nivada, Los Vegas. Retrieved from: http://digitalscholarship.unlv.edu/cgi/ viewcontent.cgi? article $=2924 \&$ context $=$ these sdissertations. On 112016-12-.

- Dadoul A, Jabareen H, Sulieman Z (2015): The Relationship between Internet Use and Psychological Health of University Students in South West Bank . Available at SSRN:http://ssrn.com/abstract $=2558148$

- Development and validation.
Psychology of Women Quarterly, 20, 181215.

- Dhir A, Pallesen S, Torsheim T, Andreassen C. (2015): Do age and gender differences exist in selfie-related behaviours? Computers in Human Behavior 63 (2016) :549555-.

- Dohnt K \& Tiggemann M. (2006): Body image concerns in young girls: The role of peers and the media prior to adolescence. Journal of Youth and Adolescence, 35,135145.

- Downs D, James SH, Cowan G. (2008): Body Objectification, Self-Esteem, and Relationship Satisfaction: A Comparison of Exotic Dancers and College Women. Journal of Sex Roles, 54 (11): 745-752. - Duggan, M \& Smith A. (2013). Social media update 2013. Retrieved November 20, 2014, from Pew Research Internet Project website :http://www.pewinternet. org/201330/12// social-media-update-2013. - Dutta E, Sharma P, Dikshit R, Shah N, Sonavane S, Bharati A, De Sousa A. (2016): Attitudes toward selfie taking in school-going adolescents: An exploratory study. Indian Journal of Psychological Medicine. 38(3): 24245-.

- $\quad$ Fox J, Rooney M . (2015): The Dark Triad and trait self-objectification as predictors of men's use and self-presentation behaviors on social networking sites. Personality and Individual Differences. 76 (April 2015): 161165.

Fredrickson B, Roberts T. (1997): Objectification Theory: Toward understanding women's lived experiences and mental health risks. Psychology of Women Quarterly, 21(2), 173206-. 
- $\quad$ Giedd, N. (2012): The digital revolution and adolescent brain evolution. Journal of Adolescent Health, 51, 101-105.

- Goldberg L. (1993): The structure of phenotypic personality traits. American Psychologist, 48, 2634-.

- Goldenberg J, Cooper D, Heflick N, Routledge C, Arndt J. 2011: Is objectification always harmful? Reactions to objectifying images and feedback as a function of selfobjectification and mortality salience. Journal of Experimental Social Psychology 47 (2011) 443-448.

Grabe Sh, Hyde J, Lindberg S . (2007): Body objectification and depression in adolescents: The role of gender, shame and rumination. Psychology of Women Quarterly, 31 (2007), 164-175.

- Gupta C. (2011): The Relation between Body Image Satisfaction and Self-esteem to Academic Behaviour in Adolescents and Preadolescents. A published Thesis. University of Manitoba. Available at: https://umanitoba. ca/faculties/education/media/Gupta-11.pdf. retrived on: 102016-8-.

- Hamilton S. (2008): The Relationship Between Perceived Body Image and Depression: How College Women See Themselves May Affect Depression. Student Journal of Psychological Science, 1(1), 1320-. - Harrison K, Fredrickson B. (2008): Women's sports media, SelfObjectification and Mental Health in Black and White Adolescent Females. Journal of Communication, 53(2): 216- 32.

- Holmqvist Gattario K. (2013): Body Image in Adolescence: Through the Lenses of Culture, Gender, and Positive Psychology. Department of Psychology, University of
Gothenburg, Sweden.

Holsen I1, Kraft P, Røysamb E. (2001): The Relationship between Body Image and Depressed Mood in Adolescence: A 5-year Longitudinal Panel Study. Journal of Health Psychology. 2001 Dec;6(6):61327-.

- Houghton D, Joinson A, Caldwell N and Marder B. ( 2013): Tagger>s Delight? Disclosure and liking behaviour in Facebook: the effects of sharing photographs amongst multiple known social circles. A Discussion Paper. Running head: Effects of information sharing in Facebook on personal relationships. Birmingham University.

Ilaria L. (2006): Body Image, Body Objectification, and Depression. Published Doctoral dissertation. Pacific University. Retrieved from: http://commons.pacificu.edu/ $\mathrm{spp} / 40$.

- John O, Srivastava S. (1999): The BigFive trait taxonomy: History, measurement, and theoretical perspectives. In L. A. Pervin \& O. P. John (Eds.), Handbook of personality: Theory and research (Vol. 2, pp. 102-138). New York: Guilford Press.

Johnson C. (2013)|: 〈Selfie syndrome> not necessarily narcissistic. Retrieved on August 17, 2014, from http:// www.komonews.com/news/local/SelfieSyndrome--228932821.html

Johnson V. (2016): Internalizing Beauty Ideals: The Health Risks of Adult Women's Self-Objectification. New York University. Department of Applied Psychology. Available at: http://steinhardt.nyu.edu/appsych/opus/ issues/2014/fall/stieflerjohnson. Retrieved on: 92016-8-.

- Jongenelis M, Byme S, Pettigrew S. (2014): Self-objectification, body image 
disturbance, and eating disorder symptoms in young Australian children. Body Image Journal, 11(3): 290302-.

- Judge, TA.; Bono, JE (2000): «Five-factor model of personality and transformational leadership». Journal of Applied Psychology. 85(5).

- Katz, Elihu, Jay G. Blumler, and Michael Gurevitch. «Uses and Gratifications Research.»The Public Opinion Quarterly 4th ser. 37 (1973-1974): 50923-.

- Keller M. (2013): Social Media and Interpersonal Communication. Social Work Today

13 ( 3): 10. Available at: http://www. socialworktoday.com/archive/051313p10. shtml.

- Kessler K.(2010): Self-Objectification, Body Image, Eating Behaviors, and Exercise Dependence among College Females. Published Thesis of Master of Science. University of North Texas. Available at: http://digital.library.unt.edu/ark:/67531/ metadc30477/m21//high_res_d/thesis.pdf. - $\quad$ Kim J, LaRose R, Peng W. (2009): Loneliness as the Cause and the Effect of Problematic Internet Use: The Relationship between Internet Use and Psychological WellBeing. CyberPsychology \& Behavior. 12(4): 451455-.

Lenhart A. Purcell K, Smith A, Zickur K. (2010):. Social Media and Young Adults. Washington, DC: Pew Research Center. .Available at: http://pewinternet.org/ Reports/2010/Social-Media-and-YoungAdults.aspx.

- $\quad$ Liss M, Erchull M. (2015): Not hating what you see: Self-compassion may protect against negative mental health variables connected to self-objectification in college women. Body Image Journal, 14 (2015) :512.

- $\quad$ Lupinetti V. (2015): Self-presentation and social media: A qualitative examination of the use of Instagram by amateur NPC female figure competitors. Published thesis. san jose state university, 2015, 137 pages; 1593220 - $\quad$ Marciniac R, Budnarowska C. (2015): Selfies: An Exploration into the Brand Effects of Visual Imagery with Earned Media. Glasgow Caledonian University. Retrieved from: http:// eprints.bournemouth.ac.uk/225842//Nottingh am\%2520presentation\%2520Ruth\%2520fin al.pptx.pdf

- Mark L; Windahl S. (1985): «The concept of audience activity». Media gratifications research: Current perspectives: 109-122.

- McCain J, Borg Z, Rothenberg A, Churillo K, Wieler P, Campbell W. ( 2015): Personality and selfies: Narcissism and the dark triad. Computer in Human Behavior. 64(2016): 12633-.

- McKay T. (2013): Female SelfObjectification: Causes, Consequences and Prevention. «McNair Scholars Research Journal, Vol. 6(1); Article 7: 5370-.

- McKinley N, Hyde J. (1996): The Objectified Body Consciousness Scale: - McLean A, Paxton S, Wertheim E and Masters J.(2015): Photoshopping the selfie: Self photo editing and photo investment are associated with body dissatisfaction in adolescent girls. Int $\mathrm{J}$ Eat Disord. 2015 Dec;48(8):113240 -.

McLeod S. (2013a): Sigmund Freud. Simply Psychology. Available at: http://www. simplypsychology.org/Sigmund-Freud.html. 
Retrived on: 162016-8-.

McLeod S. (2013b):Erik Erikson. Simply Psychology. Available at: http://www. simplypsychology.org/Erik-Erikson.html. - McQuail, Denis (2010). Mass communication theory: an introduction. London: Sage Publications. pp. 420-430. - Meeus W, Van de Schoot R, Klimstra T, Branje S. (2011): Personality Types in Adolescence: Change and Stability and Links with Adjustment and Relationships: A FiveWave Longitudinal Study. Developmental Psychology, 47(4): 1181-1195.

Mendelson B, Mendelson M, White, D. (2001): Body Esteem scale for adolescents and adults. Journal of Personality Assessment, 76(1): 90106-.

- Mostafaei A, Khalili M. (2012): The relationship between Internet addiction and mental health in male and female university students. Annals of Biological Research, 2012, 3 (9):43624366-.

Muehlenkamp J, Swanson J, Brausch A. (2005): Self-objectification, risk taking, and self-harm in college women. Psychology of Women Quarterly, 29: 2432-.

- Ní Mháirtín S. (2016):A cross cultural examination of the correlation between 'selfies', self-esteem and introversion in young people living in Ireland and Hong Kong. Retrieved from: http://www.hf.uio.no/iln/ english/research/networks/digital-humanities/ news-and-events/events/2016/pdf/abstracts/ papers/sess_1b_nimh.pdf.

Noll S, Fredrickson B. (1998): A mediational model linking self objectification, body shame, and disordered eating. Psychology of Women Quarterly, 22: 623636-.

- Nuñez C. (2013): The Self- Portrait as Self Therapy. In Loewenthal, Del, (ed.) Phototherapy and Therapeutic Photography in a Digital Age.(Pp 95106-) Florence, KY, USA: Routledge.

- O〉Keeffe G, Clarke-Pearson K. (2011): The Impact of Social Media on Children, Adolescents, and Families. American Academy of Pediatrics .Clinical Report, 127(4). Available at: http://pediatrics. aappublications.org/content/127800/4/

Pappas S. (2013): Personality Traits \& Personality Types: What is Personality?. Available at: http://www.livescience. com/41313-personality-traits.html.

Paris C, Pietschnig J. (2015): «'But first, let me take a selfie': Personality traits as predictors of travel selfie taking and sharing behaviors». Tourism Travel and Research Association: Advancing Tourism Research Globally. Paper 1. Available at: http://scholarworks.umass.edu/ttra/ttra2015/ Academic_Papers_Oral/1

- Poe ${ }^{-}$J. (2015): The Link Between "Likes" and Self-Worth: How Women Use Selfies on Instagram for Self-Presentation and the Effects of Social Comparison. 14th Annual Celebration for Undergraduate Research and Creative Performance (2015). Paper 24.

- Prichard I, Tiggemann M. (2005): Objectification in fitness centers: Selfobjectification, body dissatisfaction, and disordered eating in aerobics instructors and aerobic participants. Sex Roles, 53(1-19 :(2/ 28.

- Qadir M. (2016): Perceived SelfEsteem, Selfie-Taking Compulsive Behaviors of Students and Effects on Their Academic Career. Edupedia Publications. Retrieved from: https:/edupediapublications.org/ 
perceived-self-esteem-selfie-takingcompulsive-behaviors-of-students-andeffects-on-their-academic-career.

- $\quad$ Qiu L, Lu J, Yang SH, Qu W, Zhu T. (2015): What does your selfie say about you? Computers in Human Behavior 52 (2015) 443-49.

- Quinn D, Kallen R, Twenge J, Fredrickson B. (2005): The Disruptive Effect of Self-Objectification on Performance. Psychology of Women Quarterly, March; 30(1): 5964-.

- Reed M. (2015): Narcissism and the Selfie: Investigating Millennial Narcissism on Instagram. Honors Theses. Andrews University.Availableat:www.digitalcommons. andrews.edu/cgi/viewcontent.

cgi? article $=1108 \&$ context $=$ honors

Rosenberg M. (1965): Society and the adolescent self-image. Princeton, NJ: Princeton University Press. Available at: http:// fetzer.org/sites/default/files/images/stories/ pdf/selfmeasures/Self_Measures_for_SelfEsteem_ROSENBERG_SELF-ESTEEM.pdf. - Saguy T1, Quinn DM, Dovidio JF, Pratto F. (2010): Interacting like a body: objectification can lead women to narrow their presence in social interactions. Psychological Sciences Journal., 21(2):17882-

- $\quad$ SarabiaI,EstevezA.(2015): Sexualized behaviors on Facebook. Computers in Human Behavior 61 (2016) :219226-.

- Selfiecity. (2014): Investigating the styles of selfie in five cities across the world. The Graduate Center, City University of New York. Retrieved from: http://selfiecity.net/ .on 102015-11-.

- SeongPek L. (2016): Selfie: One Man's Trash is Another Man's Treasure. The
Interdisciplinary Circle of Science, Arts and Innovation (ICSAI). Retrieved from: http:// icsai.org/procarch/1icllce/1icllce-12.pdf on 12016-12-.

Shah P. (2015): Selfie- a New Generation Addiction Disorder-Literature Review and Updates. International Journal of Emergency Mental Health and Human Resilience. Retrieved from: http:/www. omicsonline.com/open-access/selfie-a-newgeneration-addiction-disorderliteraturereview-and-updates-15221000-4821-e227. php?aid $=60704$

- Shields N, Kane J. (2011): Social and Psychological Correlates of Internet Use among College Students. Cyberpsychology: Journal of Psychosocial Research on Cyberspace, 5(1), article 1.

Soerjoatmodjo G. (2016): I Selfie Therefore I Exist: A Preliminary Qualitative Research on Selfie as Part of Identity Formation in Adolescents. Humaniora, 7 (2), 139148 -.

- Sorokowska A, Oleszkiewicz A, Frackowiak T, Pisanski K, Chmiel A, sorokowski P. (2016): Selfies and personality: Who posts self-portrait photographs?. Personality and Individual Differences. 90 (2016): 119- 123.

- Sorokowski P, Sorokowski A, Oleszkiewicz A, Frackowiak T, Huk A, Pisanski K. (2015): Selfie posting behaviors are associated with narcissism among men. Personality and Individuals Differences. 85(2015): $12327-$.

- Stanley B; Dennis D. (2009): Mass communication theory : foundations, ferment, and future (6th ed.). Boston, MA: Wadsworth. p. 416.. Retrieved 18 October 2013. 
- $\quad$ Szymansk D, Moffitt L, Carr E. (2011): Sexual Objectification of Women: Advances to Theory and Research. The Counseling Psychologist, 39(1): 6-38.

- Tiggemann M, Slater A. (2015): The Role of Self-Objectification in the Mental Health of Early Adolescent Girls: Predictors and Consequences. Journal of Pediatric Psychology, 40 (7): 704711-

Tiggemann M, Williams E. (2012): The role of self-objectification in disordered eating, depressed mood, and sexual functioning among women: A comprehensive test of objectification theory. Psychology of Women Quarterly, 36(1): 6675-.

- $\quad$ Toma CL, Hancock JT. (2013): Selfaffirmation underlies Facebook use. Pers Soc Psychol Bull. 2013 Mar;39(3):32131-.

- Unmetric .(2014): Year of the selfie. Retrieved from <http://blog.unmetric. com/201402//year-of-the-selfie/

- Vandenbosch L, Eggemont S. (2014): The three-step process of self-objectification: Potential implications for adolescents' body consciousness during sexual activity. Body Image Journal, 11 (1): 77-80.

- Wagner Ch. (2016): The relationship between Instagram selfies and body image in young adult women. First Monday Journal. 21(9). Retrieved from: http://journals.uic.edu/ ojs/index.php/fm/article/view/63905620/

- Weiser E. ( 2015): \#Me: Narcissism and its facets as predictors of selfie-posting frequency. Personality and Individual Differences 86 (2015) 477-81.

- Wickel T. (2015): Narcissism and Social Networking Sites: The Act of Taking Selfies. The Elon Journal of Undergraduate Research in Communications. 6( 1). 
Table (1): Socio- demographic characteristics of the studied adolescents

\begin{tabular}{|l|c|c|}
\hline \multicolumn{1}{|c|}{ Socio-demographic characteristics } & $\begin{array}{c}\text { Frequency } \\
\text { (N=1432) }\end{array}$ & 19.3 \\
\hline Age & 274 & 13.4 \\
\hline $12-15$ & 193 & 60.3 \\
\hline $15-18$ & 863 & 7.0 \\
\hline $18-21$ & 102 & 100.0 \\
\hline$>21$ & 1432 & 39.1 \\
\hline Marital status & \multicolumn{3}{|l}{} \\
\hline Single & 559 & 60.9 \\
\hline Gender & 873 & 19.3 \\
\hline Male & 274 & 13.4 \\
\hline Female & 193 & 67.3 \\
\hline Level of education & 965 & \\
\hline Preparatory school &
\end{tabular}


Table (2): Minimum, maximum, means, standard deviations, skewness and kurtosis of the studied variables $(\mathrm{N}=$ 1432).

\begin{tabular}{|l|l|l|l|l|l|l|}
\hline & \multicolumn{1}{|c|}{ Min } & \multicolumn{1}{|c|}{ Max } & \multicolumn{1}{c|}{ M } & \multicolumn{1}{c|}{ SD } & Skewness & kurtosis \\
\hline Negative opinions toward selfie (ATS) & 15.00 & 68.00 & 35.02 & 12.66 & .332 & -.774 \\
\hline In- Group behaviors(ATS) & 20.00 & 46.00 & 37.65 & 3.89 & -1.450 & 3.127 \\
\hline Pastime (ATS) & 23.00 & 41.00 & 38.51 & 4.82 & -2.069 & 2.990 \\
\hline Travels (ATS) & 16.00 & 28.00 & 24.79 & 2.53 & -1.748 & 3.329 \\
\hline Status symbols(ATS) & 9.00 & 25.00 & 20.22 & 2.66 & -1.434 & 3.531 \\
\hline Privacy concerns(ATS) & 11.0 & 19.0 & 16.8 & 1.59 & -1.389 & 1.790 \\
\hline Impression management(ATS) & 13.00 & 24.00 & 20.74 & 1.90 & -.914 & 1.064 \\
\hline self objectification & -11.00 & 11.00 & 0.49 & 6.31 & -.256 & -1.284 \\
\hline Body surveillance (OBC) & 1.00 & 7.00 & 3.35 & 1.01 & -0.14 & -0.28 \\
\hline Body shame(OBC) & 1.00 & 8.00 & 5.09 & 1.03 & -0.35 & -0.65 \\
\hline Appearance control beliefs(OBC) & 1.00 & 7.00 & 4.16 & 1.22 & -0.38 & -0.31 \\
\hline Total objectified body consciousness(OBC) & 45.00 & 132.00 & 1.06 & 13.08 & -.646 & 0.856 \\
\hline body esteem & 30.00 & 90.00 & 66.68 & 17.29 & -.602 & -1.048 \\
\hline self esteem & 22.00 & 30.00 & 27.05 & 1.46 & -.744 & 0.971 \\
\hline Extraversion (BFPT) & 2.00 & 33.00 & 24.75 & 4.41 & -.144 & 0.263 \\
\hline Agreeableness(BFPT) & 29.00 & 44.00 & 37.46 & 2.80 & -.420 & 0.199 \\
\hline Conscientiousness(BFPT) & 30.00 & 53.00 & 38.08 & 2.54 & -.521 & 1.549 \\
\hline Neuroticism(BFPT) & 19.00 & 34.00 & 25.32 & 3.46 & .512 & -0.516 \\
\hline Openness to experience(BFPT) & 30.00 & 45.00 & 38.15 & 3.36 & -.262 & -0.369 \\
\hline
\end{tabular}


Table (3) Data related to selfie uses as reported by the studied adolescents

\begin{tabular}{|c|c|c|c|c|c|c|c|c|c|}
\hline \multirow[t]{2}{*}{ Items } & \multicolumn{2}{|c|}{$\begin{array}{l}\text { Preparatory } \\
\text { Students }\end{array}$} & \multicolumn{2}{|c|}{$\begin{array}{l}\text { Secondary } \\
\text { Students }\end{array}$} & \multicolumn{2}{|c|}{$\begin{array}{l}\text { University } \\
\text { students }\end{array}$} & \multicolumn{2}{|c|}{ Total } & \multirow[t]{2}{*}{$\begin{array}{c}\text { F } \\
\text { (Sig.) }\end{array}$} \\
\hline & $\begin{array}{c}\text { Frequency } \\
(\mathrm{N}-274)\end{array}$ & $\%$ & $\begin{array}{c}\text { Prequency } \\
(\mathrm{N}-193)\end{array}$ & $\%$ & $\begin{array}{c}\text { Frequency } \\
(\mathrm{N}-965)\end{array}$ & $\%$ & $\begin{array}{l}\text { Frequency } \\
(\mathrm{N}-1432)\end{array}$ & $\%$ & \\
\hline Personal & 130 & 47.4 & 101 & 52.3 & 438 & 45.4 & 669 & 46.7 & \multirow{2}{*}{$\begin{array}{l}2.247 \\
(.106)\end{array}$} \\
\hline Intimate & 20 & 7.3 & 29 & 15.0 & 146 & 15.1 & 195 & 13.6 & \\
\hline One & 4 & 1.5 & 3 & 1.6 & 7 & 0.7 & 14 & 1.0 & \multirow{5}{*}{$\begin{array}{l}2.000 \\
(.136)\end{array}$} \\
\hline $2-4$ & 3 & 1.1 & 10 & 5.2 & 13 & 1.3 & 16 & 1.1 & \\
\hline $4-6$ & 16 & 5.8 & 76 & 39.4 & 37 & 3.8 & 63 & 4.4 & \\
\hline $6-8$ & 123 & 44.9 & 104 & 53.9 & 400 & 41.5 & 599 & 41.8 & \\
\hline More than 8 & 128 & 46.7 & 3 & 1.6 & 508 & 52.6 & 740 & 51.7 & \\
\hline \multicolumn{9}{|c|}{ Selfie posting photos on sacial media sites/ day } & \multirow{4}{*}{$\begin{array}{l}55.563 \\
\left(.000^{*}\right)\end{array}$} \\
\hline $4-6$ & 61 & 22.3 & 73 & 37.8 & 244 & 25.3 & 378 & 26.4 & \\
\hline $6-8$ & 24 & 8.8 & 38 & 19.7 & 260 & 26.9 & 322 & 22.5 & \\
\hline More than 8 & 14 & 5.1 & 15 & 7.8 & 156 & 16.2 & 185 & 12.9 & \\
\hline \multicolumn{9}{|l|}{ Events accompanied selfie } & \multirow{5}{*}{$\begin{array}{c}.203 \\
(.816)\end{array}$} \\
\hline Special occasions & 102 & 37.2 & 69 & 35.8 & 334 & 34.6 & 505 & 35.3 & \\
\hline Travelling & 25 & 9.1 & 26 & 13.5 & 117 & 12.1 & 168 & 11.7 & \\
\hline Everyday activates & 140 & 51.1 & 92 & 47.7 & 481 & 49.8 & 713 & 49.8 & \\
\hline Others & 7 & 2.6 & 6 & 3.1 & 33 & 3.4 & 46 & 3.2 & \\
\hline \multicolumn{9}{|l|}{ Causes of selfie taking } & \multirow{3}{*}{$\begin{array}{l}.168 \\
(.846)\end{array}$} \\
\hline no one capture photo for me & 12 & 4.4 & 5 & 2.6 & 33 & 3.4 & 50 & 3.5 & \\
\hline because it is easy and practical & 130 & 47.4 & 103 & 53.4 & 459 & 47.6 & 692 & 48.3 & \\
\hline to document my daily activities & 60 & 21.9 & 36 & 18.7 & 313 & 32.4 & 409 & 28.6 & \multirow{4}{*}{$\begin{array}{l}.564 \\
(.569)\end{array}$} \\
\hline $\begin{array}{l}\text { to make people oriented with my } \\
\text { new experiences }\end{array}$ & 52 & 19.0 & 42 & 21.8 & 292 & 30.3 & 386 & 26.9 & \\
\hline because it make me happy & 49 & 17.9 & 38 & 19.7 & 93 & 9.6 & 180 & 12.6 & \\
\hline others (imitating others) & 7 & 2.6 & 4 & 2.1 & 21 & 2.2 & 32 & 2.2 & \\
\hline \multicolumn{9}{|l|}{ The look preffered to be in selfie } & \multirow{5}{*}{$\begin{array}{l}1.718 \\
(.180)\end{array}$} \\
\hline beautiful/ smart & 83 & 30.3 & 66 & 34.2 & 194 & 20.1 & 343 & 24.0 & \\
\hline Neutral & 100 & 36.5 & 70 & 36.3 & 508 & 52.6 & 678 & 47,3 & \\
\hline attractive/ sexy & 82 & 29.9 & 50 & 25.9 & 234 & 24.2 & 366 & 25.6 & \\
\hline Others (funny/sarcastic) & 9 & 3.3 & 7 & 3.6 & 29 & 3.0 & 45 & 3.1 & \\
\hline \multicolumn{9}{|c|}{ Use of photo editing programs before posting selfie } & \\
\hline Yes & 17 & 6.2 & 26 & 13.5 & 151 & 15.6 & 194 & 13.5 & $\begin{array}{c}8.201 \\
(000 *)\end{array}$ \\
\hline No & 257 & 93.8 & 167 & 86.5 & 814 & 84.4 & 1238 & 86.5 & \\
\hline How many times you take selfie befo & re posting & & & & & & & & \\
\hline First photo & 88 & 32.1 & 63 & 32.6 & 307 & 31.8 & 458 & 32.0 & .537 \\
\hline $2-4$ & 157 & 57.3 & 102 & 52.8 & 514 & 53.3 & 773 & 54.0 & $(.584)$ \\
\hline$>4$ & 29 & 10.6 & 28 & 14.5 & 144 & 14.9 & 201 & 14.0 & \\
\hline
\end{tabular}


Table (4): attitudes towards selfie, self objectification, objectified body consciousness, body esteem, self esteem and personality traits of the studied adolescents in relation to their level of education

\begin{tabular}{|c|c|c|c|c|c|c|c|c|c|c|}
\hline & \multicolumn{2}{|c|}{$\begin{array}{c}\text { Preparatory } \\
\text { Students } \\
(\mathrm{N}=274)\end{array}$} & \multicolumn{2}{|c|}{$\begin{array}{c}\text { Secondary } \\
\text { Students } \\
(\mathrm{N}=193)\end{array}$} & \multicolumn{2}{|c|}{$\begin{array}{c}\text { University } \\
\text { students } \\
(\mathrm{N}=965)\end{array}$} & \multicolumn{2}{|c|}{$\begin{array}{c}\text { Total } \\
(\mathrm{N}=1432)\end{array}$} & \multirow[t]{2}{*}{$\mathbf{F}$} & \multirow[t]{2}{*}{ Sig. } \\
\hline & $\mathrm{M}$ & SD & $\mathrm{M}$ & SD & $\mathrm{M}$ & SD & $\mathrm{M}$ & SD & & \\
\hline Negative opinions toward selfie (ATS) & 39.02 & 12.83 & 38.92 & 12.02 & 33.11 & 12.28 & 35.02 & 12.65 & 35,390 & $.000^{*}$ \\
\hline In-Group behaviors(ATS) & 37.28 & 4.72 & 37.77 & 3.70 & 37.72 & 3.66 & 37.65 & 3.89 & 1.521 & .219 \\
\hline Pastime (ATS) & 38.22 & 5.13 & 38.03 & 5.27 & 38.69 & 4.61 & 38.51 & 4.81 & 2.162 & .115 \\
\hline Travels (ATS) & 24.52 & 2.61 & 24.66 & 2,71 & 24.89 & 2,46 & 24.79 & 2.53 & 2.615 & .074 \\
\hline Status symbols(ATS) & 20.09 & 2.71 & 20.08 & 2.73 & 20.29 & 2.63 & 20.22 & 2.66 & 1.012 & .364 \\
\hline Privacy concerns(ATS) & 16.88 & 1.76 & 16.77 & 1.56 & 16.89 & 1.54 & 16.87 & 1.59 & 0.496 & .609 \\
\hline Impression management(ATS) & 20.70 & 2.06 & 20.67 & 1.82 & 20.76 & 1.87 & 20.74 & 1.90 & 0.291 & .748 \\
\hline Self objectification & 2.90 & 6.78 & 1.29 & 6.72 & -0.36 & 5.88 & 0.49 & 6.30 & 32.14 & $.000^{*}$ \\
\hline Objectified body consciousness $(\mathrm{OBC})$ & 1.04 & 15.97 & 1.056 & 11.52 & 1.09 & 10.38 & 1.05 & 13.08 & 166.15 & $.000^{*}$ \\
\hline Body esteem & 54,44 & 17.67 & 58.65 & 19.08 & 71.80 & 14.19 & 66.68 & 17.29 & 162,26 & $.000^{\circ}$ \\
\hline Self esteem & 26.61 & 1.82 & 26.88 & 1.74 & 27.20 & 1.23 & 27.04 & 1.45 & 19.54 & $.000^{*}$ \\
\hline Extraversion (BFPT) & 21.38 & 3.23 & 20.98 & 2.88 & 26.45 & 3.91 & 24.74 & 4.41 & 321.72 & $.000^{\circ}$ \\
\hline Agreeableness(BFPT) & 35.01 & 2.54 & 35.40 & 2,46 & 38.56 & 2.20 & 37.45 & 2,80 & 339.10 & $.000^{\circ}$ \\
\hline Conscientiousness(BFPT) & 35.24 & 2.76 & 36.51 & 1.39 & 39.18 & 1.73 & 38.07 & 2.53 & 514.40 & $.000^{*}$ \\
\hline Neuroticism(BFPT) & 25.24 & 3.13 & 23.28 & 2.11 & 25.74 & 3.61 & 25.31 & 3.45 & 42.69 & $.000^{*}$ \\
\hline Openness to experience(BFPT) & 34.95 & 2.96 & 35.59 & 2.58 & 39.56 & 2.59 & 38.14 & 3.36 & 420.32 & $.000^{*}$ \\
\hline
\end{tabular}

Note: $\mathrm{ATS}=$ Attitudes Towards Selfic; $\mathrm{OBC}=$ Objectified Body Consciousness; $\mathrm{BFPT}=$ Big Five Personality Traits.

Table (5): self objectification, objectified body consciousness, body esteem, self esteem personality traits attitudes and data related to selfie of the studied adolescents in relation to their gender

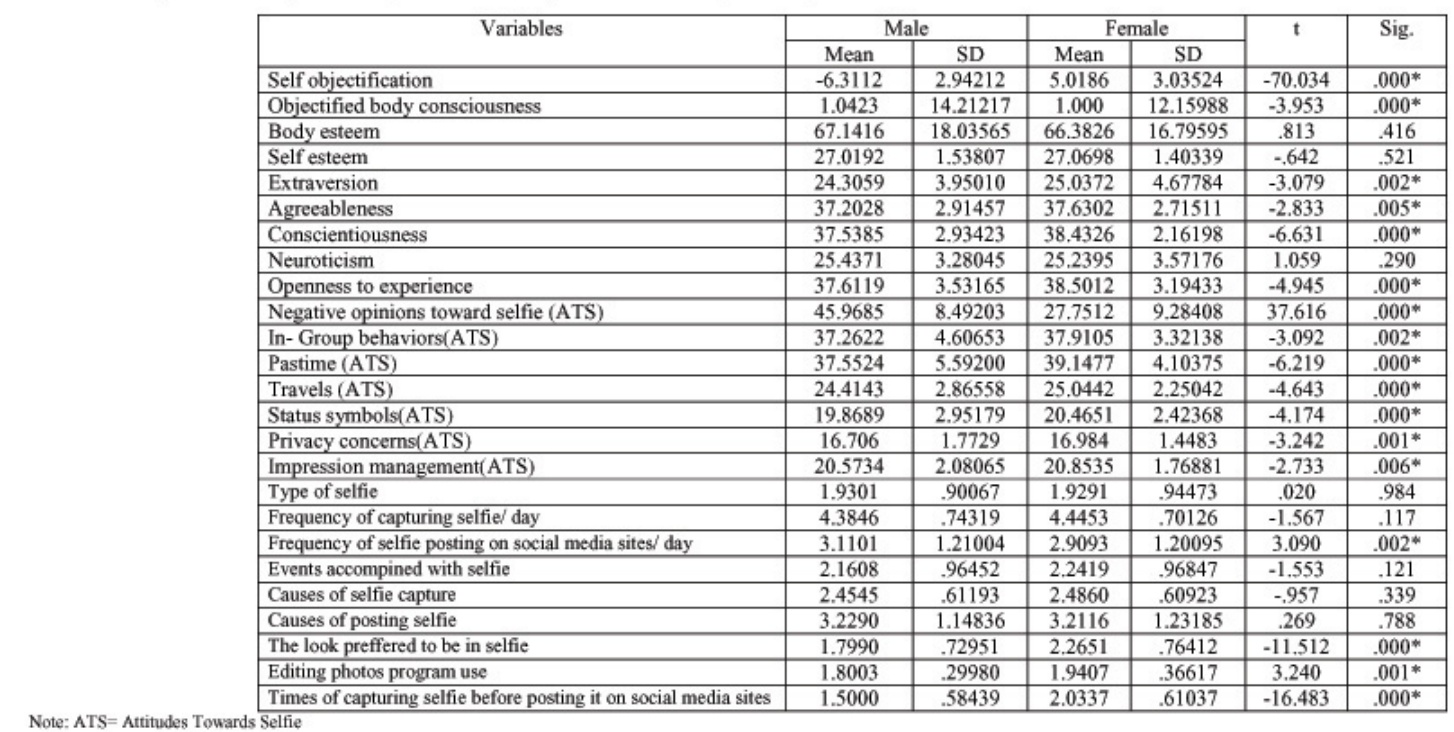

Note: ATS = Attitudes Towards Selfie 
Issue No (14 - 15) July / December - 2016

Table (6): Correlation between adolescents'attitudes towards selfic and self objoctification, objectified body consciousness, body esteem, self esteem, personality traits

\begin{tabular}{|c|c|c|c|c|c|c|c|c|c|c|c|c|c|c|c|c|}
\hline & 1 & 2 & 3 & 4 & 5 & 6 & 7 & 8 & 9 & 10 & 11 & 12 & 13 & 14 & 15 & 16 \\
\hline $\begin{array}{l}\text { Negative opinions toward selfie } \\
\text { (ATS) }\end{array}$ & - & & & & & & & & & & & & & & & \\
\hline In-Group behaviors(ATS) & -.037 & - & & & & & & & & & & & & & & \\
\hline Pastime (ATS) & $-.095^{* *}$ & $.379 * *$ & - & & & & & & & & & & & & & \\
\hline Travels (ATS) & $-.097^{* *}$ & $.224^{* *}$ & $.730^{* *}$ & - & & & & & & & & & & & & \\
\hline Status symbols(ATS) & $-.065^{*}$ & .041 & $.543^{\text {k\# }}$ & $.602^{* *}$ & - & & & & & & & & & & & \\
\hline Privacy concerns(ATS) & -.012 & $.167^{* * *}$ & $399^{* *}$ & $.310^{* * *}$ & $.584^{* *}$ & - & & & & & & & & & & \\
\hline Impression management(ATS) & -.033 & $.210^{* *}$ & $304^{* *}$ & $.457^{\circ *}$ & $.751^{* *}$ & $.648^{* 0}$ & - & & & & & & & & & \\
\hline Self objectification & $-.570^{* * *}$ & $.093^{* *}$ & $.179^{* * *}$ & $.125^{* *}$ & $.125^{* *}$ & $.097^{* *}$ & $.08^{* *}$ & - & & & & & & & & \\
\hline $\begin{array}{l}\text { Objectified body } \\
\text { consciousness(OBC) }\end{array}$ & $-.170^{* *}$ & .041 & $.112^{* *}$ & $.122^{* *}$ & $.096^{* *}$ & $.052^{*}$ & $.06 *$ & $.054^{*}$ & - & & & & & & & \\
\hline Body esteem & $-.111^{* * *}$ & -.013 & .003 & .002 & -.019 & .004 & .00 & $-.09^{* *}$ & $.134^{* * *}$ & - & & & & & & \\
\hline Self esteem & -.013 & .023 & -.025 & -.055 & -.012 & .038 & .00 & .011 & $.079 * *$ & $.074^{* *}$ & - & & & & & \\
\hline Extraversion (BFPT) & $-.228 * *$ & -.009 & -.010 & -.006 & -.021 & -.025 & -.01 & -.023 & $.191^{* * *}$ & $.339 * *$ & $.067^{*}$ & - & & & & \\
\hline Agreeableness(BFPT) & $-184^{* *}$ & .051 & .042 & .039 & .010 & .000 & .00 & -.028 & $.229 * *$ & $.312^{* *}$ & $.091^{* *}$ & $.357^{* *}$ & - & & & \\
\hline Conscientiousness(BFPT) & $-.249^{* *}$ & .042 & $.060^{*}$ & $.053^{*}$ & $.059^{*}$ & .026 & .04 & $.052^{*}$ & $364^{* *}$ & $244^{* *}$ & $.107^{* *}$ & $311^{* *}$ & $.449^{* *}$ & - & & \\
\hline Neuroticism(BFPT) & $-.052^{*}$ & .041 & $-.066^{\circ}$ & $-.056^{*}$ & $-.08^{\circ *}$ & $-.08 * 0$ & $-.07^{\star * *}$ & $-.063^{*}$ & $-07^{* *}$ & $.274^{* *}$ & .051 & $.202^{* * *}$ & $.299 * 0$ & .005 & - & \\
\hline Openness to experience(BFPT) & $-.245^{* *}$ & $.061^{*}$ & .052 & .016 & .018 & .022 & .02 & .022 & $.269 * *$ & $.275^{* *}$ & $.145^{* *}$ & $.344^{* *}$ & $.628^{* *}$ & $.550^{* *}$ & $.084^{* *}$ & - \\
\hline
\end{tabular}

Table (7): Correlation between adolescents'uses of selfie and self objectification, objectified body consciousness, body esteem, self esteem, personality traits

\begin{tabular}{|c|c|c|c|c|c|c|c|c|c|}
\hline & $\begin{array}{c}\text { Self } \\
\text { objectification }\end{array}$ & $\begin{array}{c}\text { Objectified } \\
\text { body } \\
\text { consciousness }\end{array}$ & $\begin{array}{l}\text { Body } \\
\text { esteem }\end{array}$ & $\begin{array}{c}\text { Self } \\
\text { esteem }\end{array}$ & Extraversion & Agreeableness & Conscientiousness & $\begin{array}{c}\text { Neurotisis } \\
\mathrm{m}\end{array}$ & $\begin{array}{c}\text { Oppeness } \\
\text { to } \\
\text { experience }\end{array}$ \\
\hline Type of selfie &,- 014 & -.037 &,- 033 & .024 & -.004 & .009 & .030 & -015 & .001 \\
\hline Frequency of capturing selfie/ day & .030 & .016 & -.014 & .011 & $.083^{* * *}$ & .012 & .026 & .003 & .023 \\
\hline $\begin{array}{l}\text { Frequency of selfie posting on } \\
\text { social media sites/day }\end{array}$ & $-.127^{* *}$ & $.136^{* *}$ & $.191^{* *}$ & .026 & $.170^{\circ \bullet}$ & $.174^{* * *}$ & $.165^{* *}$ & .045 & $.124^{* *}$ \\
\hline Events accompined with selfie & .018 & -.007 & -012 & .024 & -.013 & $.062^{*}$ & .008 & -.016 & $.052^{*}$ \\
\hline Causes of selfie capture & -.006 & .000 & $-.058^{\circ}$ & $.062^{\circ}$ & .029 & .008 & .042 & .012 & .008 \\
\hline Causes of posting selfie & .012 & $.069^{* *}$ & -.018 & .005 & -.005 & -.005 & .015 & .013 & -.008 \\
\hline The look preffered to be in selfie & $.239^{* *}$ & $.059^{*}$ & .002 & .019 & $.095^{* *}$ & $.098^{* *}$ & $.076^{* *}$ & .008 & $.057^{*}$ \\
\hline Editing photos program use & $-.083^{* *}$ & $-.056^{*}$ & $-.08^{* *}$ & -.005 & -.049 & $-.065^{*}$ & $-.112^{* *}$ & .008 & $-103^{* *}$ \\
\hline $\begin{array}{l}\text { Times of capturing selfie before } \\
\text { posting it on social media sites }\end{array}$ & $.369^{* *}$ & $.062^{*}$ &,- 004 & -.018 & .008 & $.079^{* *}$ & $.107^{* *}$ & -.013 & $.092^{* *}$ \\
\hline
\end{tabular}

*. Correlation is significant at the 0.05 level (2-tailed).

**. Correlation is significant at the 0.01 level (2-tailed).

Table (8): Analysis of variance

\begin{tabular}{|c|c|c|c|c|c|c|}
\hline Model & & Mean Square & $\mathrm{R}$ & $\mathrm{R}^{2}$ & $\mathrm{~F}$ & Sig \\
\hline \multirow[t]{2}{*}{1} & Regression & 35999.775 & \multirow[t]{2}{*}{.295} & \multirow[t]{2}{*}{.087} & \multirow[t]{2}{*}{135.888} & \multirow[t]{2}{*}{$.000 \mathrm{a}$} \\
\hline & Residual & 264.923 & & & & \\
\hline \multirow[t]{2}{*}{2} & Regression & 25501.545 & \multirow[t]{2}{*}{.351} & \multirow[t]{2}{*}{.123} & \multirow[t]{2}{*}{100.160} & \multirow[t]{2}{*}{$.000 \mathrm{~b}$} \\
\hline & Residual & 254.609 & & & & \\
\hline \multirow[t]{2}{*}{3} & Regression & 18038.466 & \multirow[t]{2}{*}{.361} & \multirow[t]{2}{*}{.130} & \multirow[t]{2}{*}{71,409} & \multirow[t]{2}{*}{$.000 \mathrm{c}$} \\
\hline & Residual & 252.608 & & & & \\
\hline \multirow[t]{2}{*}{4} & Regression & 14102.418 & \multirow[t]{2}{*}{369} & \multirow[t]{2}{*}{.136} & \multirow[t]{2}{*}{56.145} & \multirow[t]{2}{*}{$.000 \mathrm{~d}$} \\
\hline & Residual & 251.177 & & & & \\
\hline
\end{tabular}

a. Predictors: (Constant), self object

b. Predictors: (Constant), self object, perso diml

c. Predictors: (Constant), self object, perso diml, pers dim4

d. Predictors: (Constant), self object, perso diml, pers dim4, perso dims

e. Dependent Variable: total at 
Issue No (14 - 15) July / December - 2016

Table (9): Multiple stepwise regression analysis summary for adolescents' positive attitudes towards selfie predicting levels of self objectification, objectified body consciousness, body esteem, self esteem and personality traits

\begin{tabular}{|c|c|c|c|c|c|c|}
\hline \multirow{2}{*}{ Model } & & \multicolumn{2}{|c|}{ Unstandardized Coefficients } & \multirow{2}{*}{$\begin{array}{c}\begin{array}{c}\text { Standardized } \\
\text { Coefficients }\end{array} \\
\text { Beta }\end{array}$} & \multirow{2}{*}{$t$} & \multirow{2}{*}{ Sig } \\
\hline & & $\mathrm{B}$ & Std. Error & & & \\
\hline \multirow[t]{2}{*}{1} & (Constant) & 194.216 & .431 & & 450.167 & .000 \\
\hline & Self object & -.795 & .068 & -.295 & -11.657 & .000 \\
\hline \multirow[t]{3}{*}{2} & (Constant) & 212.376 & 2.403 & & 88.371 & .000 \\
\hline & Self object & -.807 & .067 & -.299 & $\begin{array}{l}-12.067 \\
\end{array}$ & .000 \\
\hline & Extraversion & -.734 & .096 & -.190 & -7.676 & .000 \\
\hline \multirow[t]{4}{*}{3} & (Constant) & 221.731 & 3.582 & & 61.897 & .000 \\
\hline & Self object & -.821 & .067 & -.304 & -12.302 & .000 \\
\hline & Extraversion & -.665 & .097 & -.172 & -6.845 & .000 \\
\hline & Neuroticism & -.436 & .124 & -.089 & -3.510 & .000 \\
\hline \multirow[t]{5}{*}{4} & (Constant) & 234.299 & 5.482 & & 42.739 & .000 \\
\hline & Self object & -.814 & .067 & -.302 & -12.230 & .000 \\
\hline & Extraversion & -.561 & .103 & -.145 & -5.449 & .000 \\
\hline & Neuroticism & -.430 & .124 & -.087 & -3.467 & .001 \\
\hline & $\begin{array}{l}\text { Openness to } \\
\text { experience }\end{array}$ & -.402 & .133 & -.079 & -3.022 & .003 \\
\hline
\end{tabular}

